\title{
An Actograph for Small Laboratory Animals Controlled by a Personal Computer
}

\author{
Tadao IKEDA, Takeyuki ABE and *Kenji TASHIRO \\ Department of Biology, Nihon University of School of Medicine, and \\ *Department of Physics, Nihon University of School of Medicine, \\ 30-1 Oyaguchikami-machi, Itabashi-ku, Tokyo 173, Japan
}

(Received 10 February 1987/Accepted 3 June 1987)

\begin{abstract}
This system for measuring behavioral activity and for its analysis by personal computer as the recording device of the actograph was developed in order to measure the drinking activity and the feeding activity of small laboratory animals. According to the results of the measurement on male DBA/2J mice with this actograph, $84.0 \%$ of the drinking activity occurred in the dark period while $16.0 \%$ in the light period, and the amount of water drunk by the mouse was about $5.7 \mathrm{ml} /$ day under the conditions of a 12 hour light period and 12 hour dark period. Under the same conditions, 79.6 $\%$ of the feeding activity took place in the dark period and $20.4 \%$ in the light period. Also there was a positive correlation between both activities.
\end{abstract}

On regarding recent animal experiments in various research areas such as medicine, pharmacology, toxicology, it is necessary to discuss the experimental results according to observational records of various physiological changes of the experimental animals. Therefore many different observational methods for measuring laboratory animal's biological rhythms are used depending on their experimental purposes, and the experimental techniques in these methods also have been advanced. For example, there are devices such as the autoactivity detector for small animals [2], the drinking activity detector [3], and the actograph for fish [1]. It is possible using these devices to analyze activity qualitatively as well as quantitatively. The authors have developed a system which records activity and analyzes it by using a personal computer (PC-8001 m$\mathrm{kII}, \mathrm{NEC})$ as a data recording part of the actograph. This makes possible the collection of detailed data in the activity observation of animal experiments, enable the control of analysis procedures, and increases the experimental accuracy. This paper reports discussion on that system during the activity observation(the drinking behavioral activity and the feeding behavioral activity) of mice using the actograph constructed by our group.

Fig. 2 shows an outline of the recording device. The device employs the drinking sensor (drip sensor)which was made by insertion of electrical terminal into a disposable transfusion set (TERUMO, TS-A450C). This sensor detects voltage changes at the electrical terminal which a drop of water falls on, and the feeding sensor (photo sensor) which detects voltage changes of a photo transistor (TOSHIBA, TPS 601), when beams of infrared light from a photo diode (TOSHIBA, TLN 


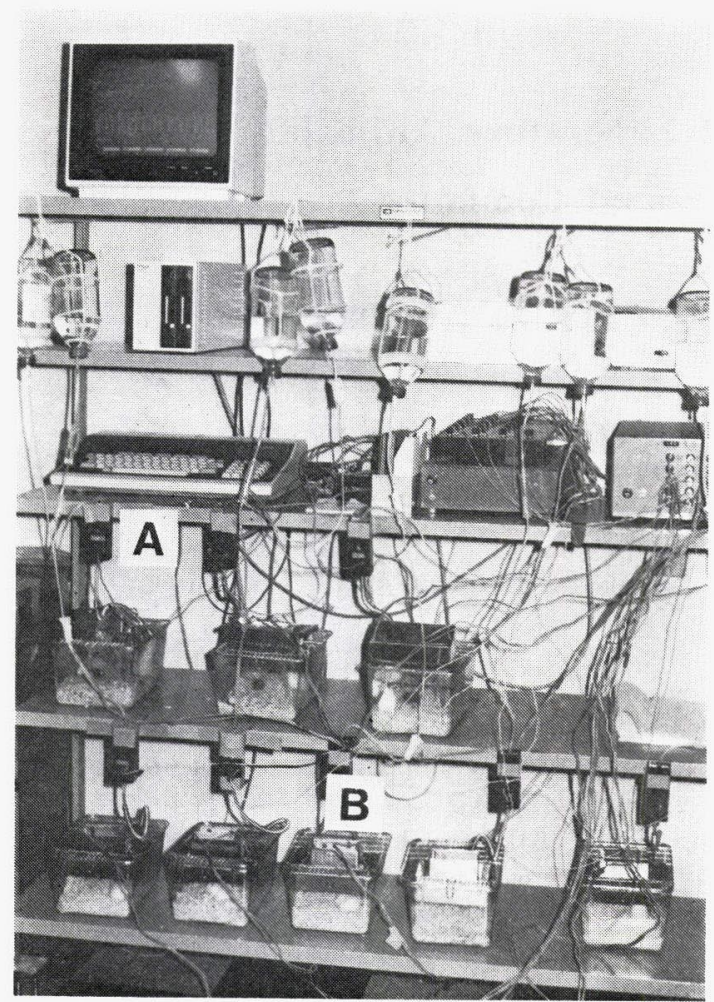

Fig. 1. The measuring apparatus for the locomotar activity of mice.

A : drip sensor B: photo sensor

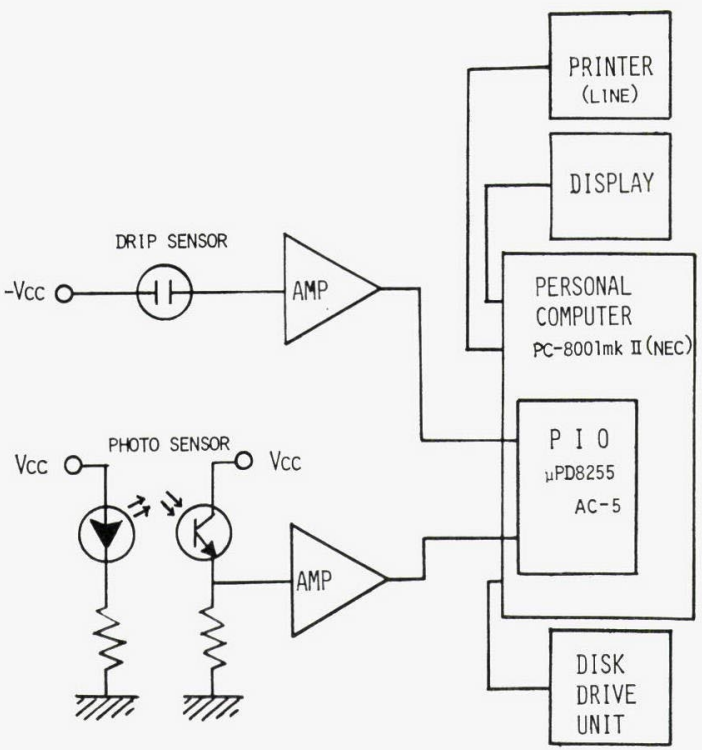

Fig. 2. Schematic diagram of the actograph controlled by a personal computer.
101) on the other side of the food server are interrupted by mice crossing the light beams. An electrical change induced by either sensor is converted into a pulse signal using the schmidt trigger circuit, and then the pulse is inputted to the computer from the data buffer through an interface. In other words, each drop of water which fall on the drip sensor when the mouse drinks water through a nozzle of the auto water server, and each interception of the light beams in the photo sensor when the mice eat food are each recorded as the value 1 . The data is read into the memory with a certain hour period, and is recorded on a floppy disk as the data file every day.

The interface was built on a commercial interfacing board which can be inserted into the mother buffer of the personal computer. The I. C. used here was a programmable multipurpose I/O device PD 8255 AC-5 (8255 A). The $8255 \mathrm{~A}$ has three sets of input-outputs, Port $\mathrm{A}\left(\mathrm{PA}_{0}-\mathrm{PA}_{7}\right)$, Port $\mathrm{B}\left(\mathrm{PB}_{0}-\mathrm{PB}_{7}\right)$, and Port $\mathrm{C}\left(\mathrm{PC}_{0}-\mathrm{PC}_{7}\right)$. The I. C. is used for input and output of the data, input of the status signal, and output of the control signal. All of these operations can be controlled by the computer program. The computer program for operating the recording device was written in BASIC language which is exclusively for the computer, and is composed of five parts : setting the condition of measurement; the measurement ; display on the CRT screen; the data output to the printer; and recording of the data file on a floppy disk. Fig. 3 shows a flow chart for the recording system of the actograph. First the number of days of duration of the measurement and the time and day of the start of the measurement are set. Then the internal clock of the computer is adjusted. The computer program compares the starting time and the present time, and the measurement will start when the both times coincide. The measurement repeats a certain number of times by using FOR-NEXT command. The data from the photo sensor and the drip sensor are read into the computer memory every 30 minutes, and are displayed on the CRT screen while outputting the data to the printer and recording the data on a floppy 


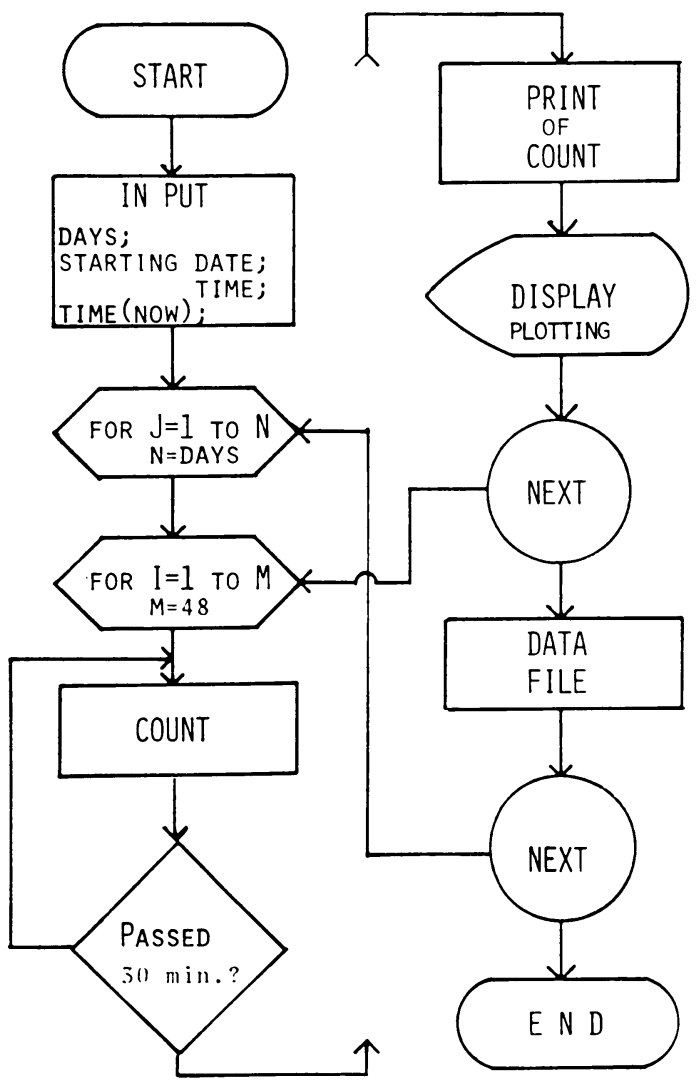

Fig. 3. Flow chart for the recording system of the actograph.

disk.

Animals used for the experiment were 1015 weeks old DBA/2J mice (male, weight : 20.0-25.0 g), raised in our laboratory. The breeding condition was set for $22 \pm 2{ }^{\circ} \mathrm{C}$ room temperature, $55 \pm 5 \%$ moisture, a ventilation frequency of 17 times/hour, and a 12 hour lighting period (the light on at 8 in the morning and off at 8 in the night: LD 12:12). The feed was a solid feed MF (ORIENTAL), and was given amply. The water was given through the nozzle of the auto water server.

Fig. 4, Fig. 5, and Fig. 6 are some results of the data analysis using the computer program. Fig. 4 shows the frequencies of the drinking behavior and the feeding behavior in a day derived from averaging the data of light. DBA/2J mice experimented with for 14 days. The major activity was observed in the dark period. The amount of water the mouse
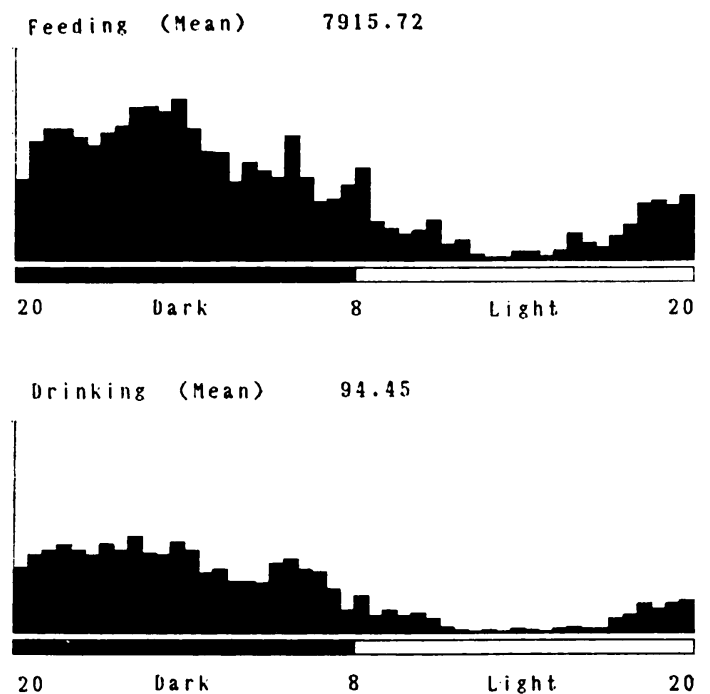

Fig. 4. Diurnal feeding activity and drinking activity pattern of $\mathrm{DBA} / 2 \mathrm{~J}$ male mice under LD $12: 12$. This figure presents the mean value of every 30 minutes counts for 14 days in a row.
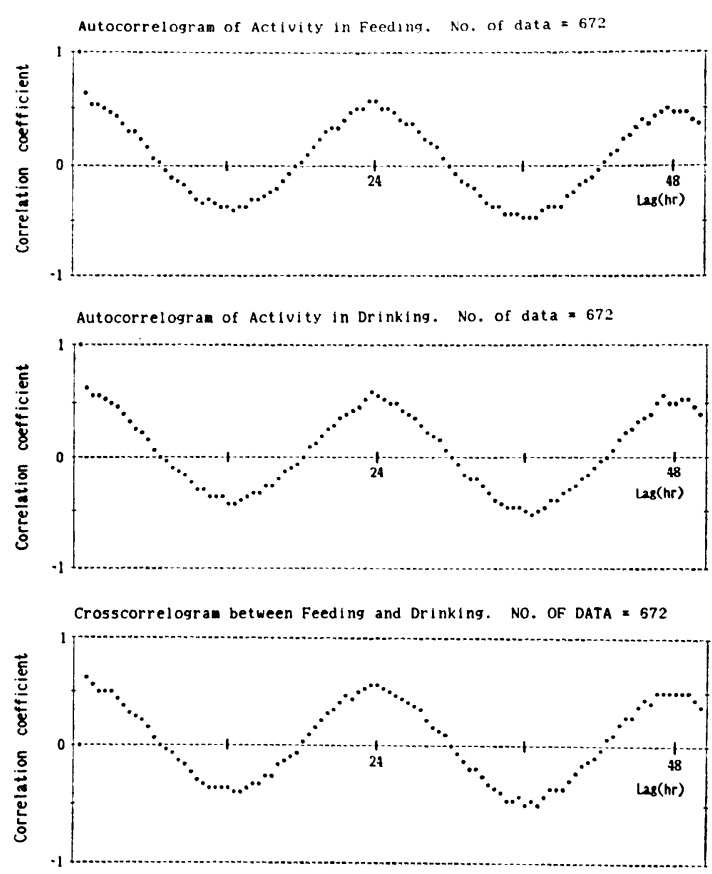

Fig. 5. Examples of time series analysis of the feeding activity and drinking activity in figure 4. Each point was calculated from the data of 14 consecutive days. 

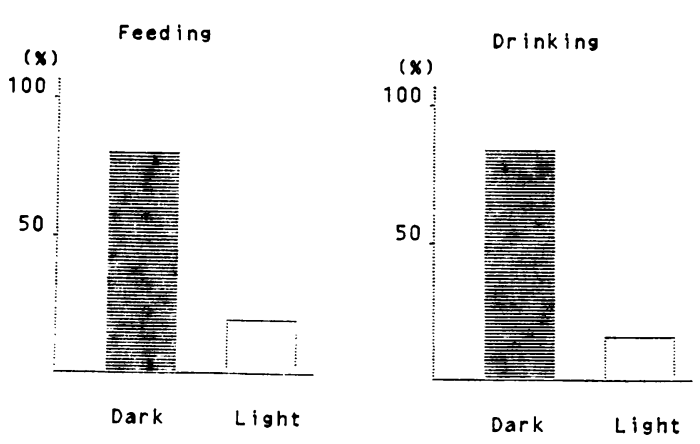

Fig. 6. The ratios of activity in the light period and the dark period when feeding and drinking activity in one day are assumed to be $100 \%$.

drunk was about $5.62 \pm 0.22 \mathrm{ml} /$ day, which was calculated from the frequency of drinking $(94.8 \pm 3.6 /$ day) and $0.06 \mathrm{ml}$ (the amount of water in each drop fell on the sensor). That amount was less than the amount of $7.5 \pm(1.9$ $\mathrm{m} l$ /day measured by a graduated cylinder everyday. The values were calculated from group of control mice which were supplied with water in a bottle. For the feeding activity $7915.7 \pm 741.5$ crossings of the light beams were observed. The time series analysis was carried out with the above data in order to find the correlation between the drinking activity and the feeding activity. The result of this analysis is shown in Fig. 5. In the condition of LD12:12, it was observed that both the drinking activity and the feeding activity of DBA/2J mice repeated every 24 hours and the rhythms of drinking and feeding were correlated. Fig. 6 shows the ratios of activity in the light period and the dark period when drinking and feeding activity in one day are assumed to be $100 \%$. About $84 \%$ of drinking activity occurred in the dark period and about $16 \%$ in the light period. The feeding activity was about $80 \%$ in the dark and about $20 \%$ in the light. The higher activity was observed in the dark period for both activities. However, these observations disagree with Tsuji and Ebihara observation [4] that no activity occurred in the light period.

Using the personal computer with the interface described above as the recording part of the actograph, the data processing capability is increased compared to the traditional analog recorder. Namely, the data of the activity can be recorded numerically and also information from the data can be derived with higher efficiency by adding computer programs for statistical analysis and time series analysis.

One problem measuring with this recording device is error signal due to electrical noise such as noise created by turning on-off the light switch which was not eliminated by the schmidt trigger circuit. Therefore the electrical wires connecting the recording part and the sensoring part of the device were shortened, and the background noise alone was measured using the actual recording device without mice in order to find the effects, of the error signal. Since it is not possible to read all of the data at once when many sensors are used, it is necessary to use a buffer device which stores the data for a certain period of time, or else to write the program in machine languages. The activity recording device built by this group in can record the data on a floppy disk. Therefore the data can be picked up any time and be analyzed in a short period of time with the various analysis programs. Because of these advantages this recording device has high practicality for measuring activity rhythm or amount of activity.

\section{References}

[1] Abe, T.(1983). Bull. Lib. Arts \& Sci. Course, Nihon Uni. Sch. Med., 11, 29-36.

[2] Saito, R. T., Sano, J., and Takahashi, K. W. (1979). Exp. anim., 28, 313-316.

[3] Saito, R. T., and Takahashi, K. W. (1979). Exp. Anim., 28, 405-407.

[4] Tsuji, K., and Ebihara, S.(1980). Metabolism and I)isease (suppl), 17, 115-128. 


$$
\text { パーソナルコンピュータ制御による }
$$

\section{実験小動物の活動記録計}

池田忠生・阿部健之.*田代健治

日本大学医学部生物学教室

*日本大学医学部物理学教室

実験小動物の飲水行動（量）および提食行動（量）を 測定する目的で, 活動記録計装置（アクトグラフ）の記 録部としてパーソナル・コンピュータを用い, 活動量の 測定とその解析を行う一連のシステムを考案した。本了 クトグラフを用いて $\mathrm{DBA} / 2 \mathrm{~J}$ マウスのオスの行動を調
べた結果， 12 時間の明期と 12 時間の暗期の条件下におけ る飲水行動（暗期：84.0\%, 明期：16.0\%）および摄食 行動（暗期：79.6\%, 明期：20.4\%）は24時間の周期で 繰り返した。さらに，てれらの行動は相関を示した。飲 水量をあとめると約 $5.7 \mathrm{ml} /$ 日であった。 